\title{
AKTUALISASI SEMANGAT KEBANGSAAN DALAM MENYIKAPI WABAH COVID 19 DI SMP MUHAMMADIYAH 1 PURWOKERTO
}

\author{
Elly Hasan Sadeli' ${ }^{1}$ Eko Priyanto' ${ }^{2}$ Banani Ma'mur ${ }^{3}$ \\ 1,2,3Program Studi Pendidikan Pancasila dan Kewarganegaraan, Fakultas Keguruan dan \\ Ilmu Pendidikan, Universitas Muhammadiyah Purwokerto \\ 1,2,3Jl. K.H. Ahmad Dahlan PO. Box 202 Purwokerto 53182 Tlp. (0281) 636751 \\ ${ }^{1}$ Email: ellyhasansadeli@ump.ac.id* \\ 2Email: ekopriyanto@ump.ac.id \\ ${ }^{3}$ Email: bananima'mur@ump.ac.id
}

\begin{abstract}
ABSTRAK
Penelitian ini bertujuan untuk mendapatkan informasi aktual dan faktual tentang aktualisasi semangat kebangsaan dalam menyikapi wabah covid 19 di SMP Muhammadiyah 1 Purwokerto. Proses penelitian menggunakan pendekatan kualitatif dengan metode studi kasus. Teknik pengumpulan data dilakukan melalui observasi, wawancara, studi dokumentasi dan studi literatur. Penelitian ini dilakukan pada proses pembelajaran Pendidikan Pancasila dan Kewarganegaran (PPKn). Subjek penelitian adalah kepala sekolah, guru PPKn dan siswa. Temuan dalam penelitian ini menunjukkan bahwa; 1) Siswa belum memiliki pemahaman yang utuh terhadap konsep wawasan kebangsaan, namun secara implisit dalam proses pembelajaran PPKn, guru senantiasa membangun iklim kebersamaan dan saling membantu. Kondisi ini sebenarnya dapat dipahami jika benih-benih semangat kebangsaan telah muncul. Pemilihan metode pembelajaran yang bervariatif digunakan oleh guru PPKn dan guru IPS, yang menunjang terhadap sikap kebangsaan siswa. Pembelajaran PPKn dan IPS yang dilaksanakan memberikan kontribusi yang cukup besar dalam membentuk semangat kebangsaan siswa di sekolah yang ditandai dengan arah pencapaian keberhasilan belajar yang tidak hanya melihat aspek kognitif saja, namun dititikberatkan pula pada aspek afektif dan psikomotor khususnya yang bermuatan nilai-nilai kebangsaan. 2) Memperkuat organisasi dengan pondasi semangat nasionalisme yang dilandasi oleh ideologi negara dan nilai-nilai Muhammadiyah. Melalui komitmen organisasi yang kuat, maka semangat kebangsaan mengalir dalam diri siswa. 3) Praktik semangat kebangsaan siswa diwujudkan melalui partisipasinya dalam kegiatan pramuka (kepanduan Hizbul Wathan/ HW), kegiatan upacara bendera, kompetisi olahraga, serta acara kesenian daerah merupakan bentuk rangsangan dalam mengembangkan nilai-nilai kebangsaan dalam diri siswa dan tidak menyebarkan berita hoax tentang pandemi covid 19.
\end{abstract}

Kata Kunci: Aktualisasi, semangat kebangsaan dan pandemi Covid 19

\begin{abstract}
This research aims to get actual and factual information about the actualization of the national spirit in responding to the covid 19 outbreak at Muhammadiyah 1 Purwokerto Junior High School. The research process uses a qualitative approach with case study methods. Data collection techniques are carried out through observation, interviews, documentation studies and literature studies. This research was conducted on the learning process of Pancasila Education and Citizenship (PPKn). Subjekresearch is the principal, teacher PPKn and student. The findings in this study show that; 1) Students do not yet have a complete understanding of the concept of national insight, but implicitly in the process of learning PPKn, teachers always build a climate of togetherness and help each other. This
\end{abstract}


condition can actually be understood if the seeds of the national spirit have appeared. The selection of varied learning methods is used by PPKn teachers and IPS teachers, which support the national attitude of students. PPKn and IPS learning carried out contributes considerable in shaping the national spirit of students in school which is characterized by the direction of achievement of learning success that not only looks at cognitive aspects, but also emphasized on affective and psychomotor aspects, especially those that are charged with national values. 2) Strengthening the organization with the foundation of the spirit of nationalism based on state ideology and Muhammadiyah values. Through a strong organizational commitment, the spirit of nationality flows in students. 3) The practice of the student's national spirit is realized through its participation in scouting activities (Hizbul Wathan/ HW scouting), flag ceremony activities, sports competitions, and regional arts events are a form of stimulation in developing national values in students and not spreading hoax news about the covid 19 pandemic.

Keywords: Actualization, national spirit and Covid 19 pandemic

\section{PENDAHULUAN}

Indonesia adalah negara yang memiliki keberagaman yang sangat kompleks atau sering dikatakan sebagai sebuah negara yang majemuk. Kondisi ini dapat dilihat dari jumlah penduduk yang kurang lebih sebanyak 270 juta jiwa. Tentu saja, ini merupakan suatu anugerah dari Tuhan Yang Maha Kuasa yang telah memberikan segala kekayaan yang ada di nusantara, sekaligus bila tidak mampu merawatnya menjadi permasalahan yang sangat rumit.

Oleh karena itu, kondisi keberagaman ini juga memiliki potensi yang dapat melahirkan berbagai bentuk ancaman, salah satunya ancaman disintegrasi. Bahkan akhir-akhir ini Indonesia kembali dihadapkan pada persoalan yang mengancam kebhinekaan dengan munculnya berbagai praktik intoleransi yang memperuncing unsur SARA. Dengan banyaknya permasalahan mulai dari penyebaran fitnah melalui pemberitaan yang minim kebenarannya atau hoax, aksi demonstrasi yang anarkis, kasus penistaan agama, kejadian bom bunuh diri dan pembakaran tempat ibadah serta gerakan ISIS yang sampai sekarang masih terjadi.

Saat ini seluruh negara benar-benar dibuat tidak berdaya dengan menjangkitnya suatu virus. Bagaimana tidak, sebagai bentuk tanggung jawabnya para pemimpin negara berlomba-lomba membangun proteksi bagi negara dan warganya agar tidak terkena dampak dari virus tersebut. Virus yang bernama Korona (Covid 19) dan disinyalir berasal dari negeri tirai bambu, tepatnya dari Kota Wuhan telah meluluh lantahkan seluruh aktivitas sosial dan ekonomi warga dunia, bahkan telah banyak merenggut korban jiwa. Dibalik ancaman kematian dan kecemasan akibat pandemik korona, justru semakin memperkuat solidaritas masyarakat, misalnya saja masyarakat Wuhan saling memberikan semangat dengan yel-yel 
"Wuhan, kamu pasti bisa". Tidak ketinggalan warga Italia mengibarkan bendera dari jendela rumah dan konglomerat Amerika memberikan donasi untuk kepentingan riset untuk menghasilkan vaksin atau penawar korona.

Tidak terkecuali negara Indonesia yang juga terdampak oleh virus ini. Indonesia benarbenar berusaha keluar dari cobaan ini. Munculnya pendemi covid-19 membuat dunia menjadi resah, termasuk di indonesia. Pemerintah bahkan berupaya keras agar seluruh warga masyarakat dapat terhindar dari cengkeraman virus tersebut. Berbagai cara dilakukan seluruh elemen di pemerintah, mulai dari anjuran hidup sehat, kebijakan tentang social distancing serta mengeluarkan anggaran khusus dalam rangka penanganan virus tersebut.

Penting kiranya pemerintah dan institusi pendidikan bersinergis bahu-membahu untuk saling mendukung setiap kebijakan yang diambil. Namun disisi lain, pemerintah juga harus tegas dan transparan dalam memberikan informasi terkait kasus-kasus yang telah terjadi. Sehingga masyarakat tidak lantas mengalami depresi atau bahkan mendapatkan informasi yang keliru dari sumber lain yang tidak jelas dan dikhawatirkan berujung pada kondisi saling menyudutkan baik secara vertikal maupun horizontal.

Secara historis, fakta semangat kebangsaan Indonesia cukup menarik. Di Indonesia bangsa mendahului negara. Kita dapat melihat bagaimana momentum Sumpah Pemuda lahir 17 tahun sebelum proklamasi kemerdekaan, para pemuda dari seluruh nusantara sudah menyatakan tekad mereka sebagai satu bangsa. Dalam membangun semangat kemerdekaan, Bung Karno dalam sidang BPUPKI 1 Juni 1945 mengatakan bahwa kita bukan saja harus mendirikan negara Indonesia merdeka, tetapi harus menuju pula kepada kekeluargaan bangsa-bangsa... Kita hendak mendirikan suatu negara "semua untuk semua", "satu buat semua, semua buat satu"... Karena itu, jikalau tuan-tuan terima baik, marilah kita mengambil sebagai dasar negara yang pertama: Kebangsaan Indonesia (Yudi Latif, 2015). Artinya dengan adanya musibah ini, kita dapat menjadikan sebagai momen titik balik untuk kembali merawat semangat kebangsaan yang selama ini dirobek oleh kepentingan para elit dalam berebut kuasa. Jiwa Pancasila tidak terpancar sebagai kepribadian dan jati diri bangsa, namun lebih kepada sebatas lip service yang penuh dengan kepura-puraan semata.

Setiap masyarakat pasti akan mengalami suatu perubahan. Kesadaran sosial di dalam kehidupan masyarakat mempengaruhi sistem sosialnya, termasuk pengetahuan, pemahaman, sikap dan perilaku diantara kelompok masyarakat, sehingga kesadaran-kesadaran mana kemudian mempengaruhi segi-segi struktur masyarakat lainnya.

Indonesia adalah negara yang memiliki keberagaman yang sangat kompleks atau sering dikatakan sebagai sebuah negara yang majemuk. Kondisi ini dapat dilihat dari jumlah 
penduduk yang kurang lebih sebanyak 250 juta jiwa. Tentu saja ini merupakan suatu anugerah dari Tuhan Yang Maha Kuasa yang telah memberikan segala kekayaan yang ada di nusantara, sekaligus bila tidak mampu merawatnya menjadi permasalahan yang sangat rumit.

Pemerintah dan masyarakat sepakat bahwa korona merupakan musuh bersama, maka harus diselesaikan secara bersama pula. Sejatinya pemerintah tidak hanya memberikan anjuran semata akan tetapi juga memberikan solusi yang tepat, agar tidak terjadi kepanikan dan korban jiwa yang bertambah banyak. Disisi lain, masyarakat juga harus mematuhi setiap anjuran dan mendukung kebijakan pemerintah sebagai upaya penyelamatan. Serta menambah pengetahuan yang cukup tentang korona, sehingga tidak terombang-ambing dalam gelombang informasi yang penuh dengan kebohongan (hoax). Maka penting kiranya untuk memperkuat kesadaran sosial khususnya dilingkungan institusi pendidikan dalam kerangka sikap kebangsaan, sehingga dapat menumbuhkan semangat kebersamaan dalam menyelesaikan persoalan wabah ini.

Generasi muda diberi amanat untuk mengemban tugas menjalankan dan memimpin bangsa Indonesia dikemudian hari yang mempunyai keinginan, cita-cita yang mengarah ke masa depan dan sebagai generasi yang dinamis, inovatif untuk kepentingan bangsa yang pada akhirnya akan menjadi seseorang yang mempunyai jiwa dan semangat nasionalisme. Program pembelajaran yang memiliki peranan dalam memberikan kemampuan sebagai seorang warga negara yang menjunjung tinggi semangat nasionalisme, salah satunya melalui pelajaran Pendidikan Pancasila dan Kewarganegaraan (PPKn). PPKn merupakan mata pelajaran di sekolah yang memfokuskan pelajarannya pada pembentukan diri yang beragam dari segi agama, sosio kultural, usia dan suku bangsa untuk menjadi warga negara Indonesia yang cerdas, terampil dan berkarakter sesuai yang diamanatkan oleh Pancasila dan UUD NRI 1945.

Benih-benih nilai kebangsaan sebenarnya sudah hadir dalam jati diri setiap warga. Sejarah menunjukkan bahwa kebangkitan nasional memberikan bukti nyata bahwa kehadiran bangsa mendahului terbentuknya negara, ini menggambarkan bahwa begitu besarnya semangat kebangsaan sebagai cikal bakal kelahiran nasionalisme di Indonesia. Pondasi central value yang kokoh yang sejak lama sudah ada di dalam hati warga negara sebagai landasan yang sangat kuat untuk menyelesaikan berbagai permasalahan mendasar yang sedang dihadapi bangsa. Jika dulu musuh bersama bernama penjajahan, maka saat ini musuh bersama bernama kemiskinan, pengangguran, hutang, korupsi, lemahnya perekonomian serta rentannya keadaan politik dan keamanan. Dengan sumber daya yang 
tersedia dan upaya nyata, serius, sungguh-sungguh dan konsisten melalui kerja keras, maka perlu diupayakan perlawanan dalam menyelesaikan persoalan bangsa dan negara.

\section{METODE PENELITIAN}

Penelitian ini menggunakan pendekatan kualitatif. Creswell (1998:15) mendefinisikan penelitian kualitatif sebagai berikut:

"Qualitative research is an inquiry process of understanding based on distinct methodological traditions of inquiry that explore a social or human problem. The researcher builds a complex, holistic picture, analyses words, reports detailed views of informants, and conducts the study in a natural setting".

Kutipan di atas dapat dijelaskan bahwa penelitian kualitatif adalah proses penelitian untuk memahami berdasarkan tradisi metodologi penelitian tertentu dengan cara menyelidiki masalah sosial atau manusia. Peneliti membuat gambaran kompleks bersifat holistik, menganalisis kata-kata, melaporkan pandangan-pandangan para informan secara rinci, dan melakukan penelitian dalam situasi alamiah.

Metode yang digunakan dalam penelitian ini adalah metode studi kasus. Menurut Stake (Lincoln dan Guba, 1985: 341) bahwa metode ini dilakukan secara intensif, terperinci dan mendalam terhadap suatu kelompok, organisasi, lembaga atau gejala tertentu. Metode studi kasus lebih menitik beratkan pada suatu kasus, adapun kasus yang dimaksud dalam penelitian ini adalah persepsi mahasiswa terhadap nilai-nilai demokrasi Pancasila dalam menangkal radikalisme. Kasus tersebut dibatasi dalam suatu ruang lingkup kegiatan kepanduan Hizbul Wathan di SMP Muhammadiyah 1 Purwokerto. Penelitian ini lebih banyak menggunakan pendekatan antar personal, artinya selama proses penelitian berlangsung, peneliti akan lebih banyak mengadakan kontak atau berhubungan dengan orang-orang dilingkungan lokasi penelitian.

Dalam penelitian ini, teknik pengumpulan data dan informasi yang digunakan adalah teknik pengumpulan data kualitatif, yang meliputi:

- Observasi

Observasi adalah teknik pengumpulan data/ informasi yang utama dalam penelitian naturalistik inkuiri, dengan mengamati kegiatan secara langsung yang dilakukan guru PPKn dan siswa.

- Wawancara

Lincoln dan Guba, (1985: 268), mengartikan bahwa wawancara adalah suatu percakapan yang bertujuan untuk mendapatkan informasi tentang perorangan, kejadian, 
kegiatan, perasaan, motivasi, kepedulian, disamping itu dapat mengalami dunia pikiran dan perasaan responden.

Dengan menggunakan teknik wawancara data yang belum jelas berupa ucapan, pikiran, gagasan, perasaan dan tindakan dari guru dan siswa dapat terungkap oleh peneliti secara akurat. Untuk memperoleh keterangan yang ada kaintannya dengan penelitian yang dilaksanakan, maka dilakukan tanya jawab dengan guru PPKn, kepala sekolah dan siswa sebagai sumber yang dapat dipercaya atau pihak-pihak terkait yang dapat memberikan masukan bagi penelitian. Dalam hal ini penelitì mengajukan beberapa pertanyaan yang langsung dilontarkan pada sumber dan diperolehlah jawaban lebih lanjut

- Studi Dokumentasi

Untuk melengkapi data dalam rangka menganalisis masalah yang sedang diteliti, kita memerlukan informasi dari dokumen-dokumen yang ada hubungannya dengan objek yang dipelajari. Adapun dokumen dalam penelitian ini seperti struktur organisasi, visi dan misi sekolah, serta dokumen lainnya yang relevan dengan penelitian.

- Studi Literatur

Studi literatur, yaitu alat pengumpul data untuk mengungkapkan berbagai teori yang relevan dengan permasalahan yang sedang dihadapi atau diteliti sebagai bahan pembahasan hasil penelitian. Studi literatur dilakukan melalui mempelajari buku yang ada kaitannya dengan masalah yang diteliti, jurnal dan atau artikel-artikel yang relevan, surat kabar baik cetak maupun elektronik.

Proses analisis data dalam penelitian ini dilakukan secara terus menerus dari awal sampai akhir penelitian. Nasution (1988: 129) mengemukakan bahwa: tidak ada suatu cara tertentu yang dapat dijadikan pedoman bagi semua penelitian, salah satu cara yang dapat dianjurkan mengikuti langkah-langkah berikut: 1) reduksi data, 2) display data, 3) pengambilan kesimpulan dan verifikasi.

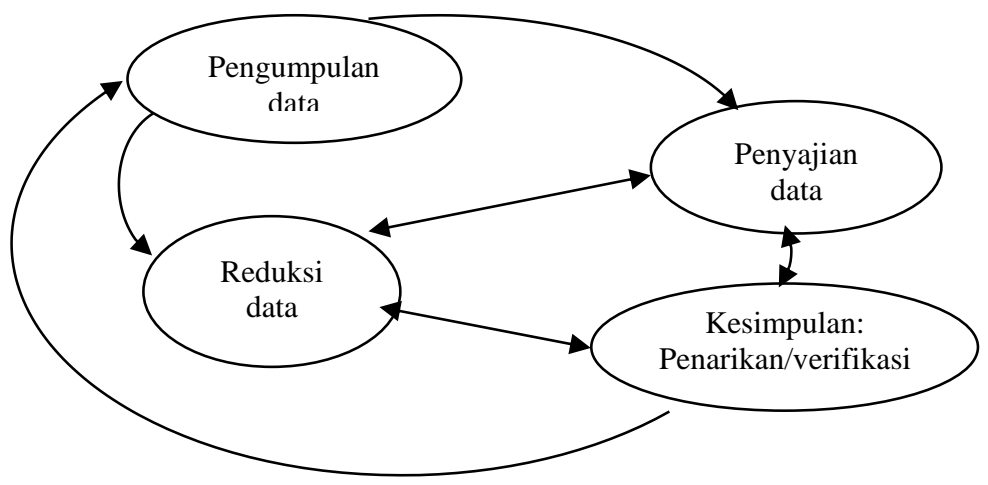

Bagan 1. Komponen-komponen Analisis Data (Miles dan Huberman, 1992: 20) 
Bagan di atas dapat dijelaskan bahwa tiga jenis kegiatan utama pengumpulan data (reduksi data, penyajian data, penarikan kesimpulan/ verifikasi) merupakan proses siklus interaktif.

\section{HASIL DAN PEMBAHASAN}

\section{Siswa belum memiliki pemahaman yang utuh terhadap konsep Kebangsaan}

Pemahaman siswa masih cukup sederhana dalam memahami konsep kebangsaan, pemahamannya lebih cenderung hanya terbatas pada bentuk yang praktis. Bahkan sejak bergulirnya reformasi, orang enggan berbicara tentang semangat kebangsaan, karena dipandang bahwa belum mampu untuk mengantar bangsa Indonesia menuju kemajuan bangsa. Bahkan ada yang berkesimpulan bahwa bangsa Indonesia saat ini mengalami kemerosotan dan krisis multidimensional.

Pandangan tersebut tidak sepenuhnya salah, sikap masyarakat terhadap pemahaman kebangsaan memang mengalami kondisi yang kurang ideal. Bahkan sebagai salah satu indikator pemahaman masyarakat terhadap konsep kebangsaan dapat ditunjukkan melalui keyakinanya terhadap ideologi Pancasila. Sangat ironis, ketika Survei Unit Kerja Presiden Pembinaan Ideologi Pancasila (UKP PIP) 2018 menemukan bahwa dari 100 orang di negara kita itu masih ada 18 orang yang tidak hapal lirik lagu kebangsaan dan 24 orang dari 100 orang tidak hafal sila-sila dari Pancasila. Mengapa hal tersebut bisa terjadi ? Ternyata setelah sekitar 2 dekade era reformasi bergulir, dengan meninggalkan Pancasila dan mencoba untuk menerapkan prinsip atau asas lain, kehidupan perpolitikan, ekonomi dan kemasyarakatan nyatanya tidak bertambah baik, akan tetapi bertambah tidak teratur.

Oleh karena itu, perlu upaya secara terencana dan terpadu dalam rangka peningkatan pemahaman tentang kebangsaan. Maka, sekolah merupakan institusi yang sangat strategis dalam mengembangkan pemahaman kebangsaan. SMP Muhammadiyah 1 Purwokerto kemudian mengembangkannya melalui pembelajaran IPS dan PPKn. Siswa mendapatkan dan memahami materi tentang kebangsaan pada pembelajaran IPS dan PPKn tersebut. Menurut guru IPS dan PPKn SMP Muhammadiyah 1 Purwokerto, konsep kebangsaan itu penting, karena kecintaan terhadap tanah air sebagai bagian dari usaha untuk menjaga keutuhan negara yang didasarkan rasa patriotisme.

PPKn pada dasarnya adalah belajar tentang keindonesiaan, belajar untuk menjadi manusia yang berkepribadian Indonesia, membangun rasa kebangsaan, dan mencintai tanah air Indonesia. Oleh karena itu, seorang sarjana atau professional sebagai bagian dari masyarakat Indonesia yang terdidik perlu memahami tentang Indonesia, memiliki 
kepribadian Indonesia, memiliki rasa kebangsaan Indonesia, dan mencintai tanah air Indonesia. Dengan demikian, ia menjadi warga negara yang baik dan terdidik (smart and good citizen) dalam kehidupan masyarakat, bangsa, dan negara yang demokratis.

Di tingkat persekolahan mata pelajaran yang memiliki visi dan misi yang jelas adalah PPKn. Hal ini sebagaimana dikemukakan oleh Winataputra dkk (2007: 2), bahwa: “... PPKn dapat disikapi sebagai: pendidikan kewarganegaraan, pendidikan politik, pendidikan nilai dan moral, pendidikan kebangsaan, pendidikan kemasyarakatan, pendidikan hukum dan hak asasi manusia, dan pendidikan demokrasi”. Kemudian Winataputra dkk (2007: 3), mengemukakan bahwa: "Secara keseluruhan Pendidikan Kewarganegaraan memiliki fungsi yang strategis untuk mewujudkan esensi tujuan pendidikan nasional membentuk warga negara yang demokratis dan bertanggung jawab".

Menurut Zamroni (2011: 25-26) dalam masyarakat yang demokratis, warga masyarakat akan taat, patuh dan tunduk pada peraturan, prinsip tersebut ingin diaplikasikan di sekolah. Kepala sekolah, guru dan orang tua cenderung memiliki kesepakatan bahwa hendaknya peraturan sekolah disusun dengan melibatkan seluruh stakeholder, khususnya orang tua siswa dan siswa sendiri.

Maka, perlu ada semangat untuk mengembangkan dan mengaplikasikan konsep kebangsaan pada kehidupan sekolah, bahkan pada kehidupan di kelas. Disamping sebagaimana dikemukakan, bahwa jiwa dan karakter kebangsaan yang ada pada diri seseorang tidaklah tumbuh secara alami, melainkan sebagai hasil suatu rekaya sosial, khususnya pendidikan yang memiliki peran strategis untuk mengembangkan jiwa dan karakter tersebut pada diri siswa.

\section{Organisasi sebagai Salah Satu bagian dari Pondasi Sikap Kebangsaan}

Kemerdekaan Indonesia yang diperoleh pada tanggal 17 Agustus 1945 tidak bisa dilepaskan dari semangat kebangsaan dan patriotisme. Para pahlawan terdahulu telah berjuang mati-matian demi kemerdekaan bangsa ini. Sebagai warga negara Indonesia, sudah sepatutnya menghargai perjuangan yang dilakukan oleh para pahwalan. Bentuk penghargaan tersebut dapat dilaksanakan dengan menerapkan semangat kebangsaan dan patriotisme dalam kehidupan berbangsa dan bernegara.

Hal tersebut dapat diaktualisasikan melalui berbagai cara, salah satu langkah yang paling tepat adalah melalui organisasi, sebagai tempat untuk berproses dan berdinamika supaya menjadi siswa yang siap dalam melanjutkan tongkat estafet kepemimpinan negara ini. 
Selain melalui pembelajaran di kelas, siswa menyampaikan bahwa konsep kebangsaan secara aplikatif didapatkan melalui kegiatan ekstrakurikuler seperti pramuka dan HW. Serta didapatkan pula dari berbagai kegiatan di masyarakat, dan pemberitaan di surat kabar cetak maupun elektronik.

Berdasarkan hasil temuan penelitian, kegiatan ekstrakurikuler di sekolah senantiasa mempraktikan semangat kebangsaan yang didasarkan pada nilai Pancasila, cintai negeri ini seperti mencintai tubuh yang sendiri dengan menampilkan budi pekerti, beribadah yang benar dan bertoleransi. Semangat kebangsaan terpancar seperti penghormatan kepada bendera, tidak menyebarkan berita hoax dan tidak terlibat hal-hal negatif. Dalam memberikan pemahaman kepada seluruh siswa terkait dengan membangun kultur kebangsaan yaitu dengan memberikan materi bahwa Indonesia berdiri dari jerih payah para syuhada maka perlu penanaman sedini mungkin untuk mencintai negeri ini diawali dari penanaman disiplin diri.

Menumbuhkah kesadaran kebangsaan memang bukan persoalan yang mudah, karena harus dibangun dari idealisme yang melekat pada diri seseorang. Selama orang itu tidak memiliki idealisme sebagai bangsa yang bersatu dalam realitas kebhinekaannya, maka kesadaran akan nasionalisme itu masih perlu terus dibentuk.

Bahkan dalam tinjauan sejarah kebangsaan Indonesia, pada saat kongres dalam momentum sumpah pemuda, awalnya masih berupaya untuk menyatukan semangat persatuan yang selama ini masih bersifat kedaerahan. Kemudian agar perjuangan semakin mudah maka para pemuda dari berbagai daerah bergabung menjadi satu Pemuda Indonesia, dengan mengambil suatu keputusan bersejarah yang menentukan bentuk Indonesia untuk masa mendatang. Dalam kongres tersebut diambil pula keputusan, bahwa lagu Indonesia Raya yang dikarang oleh W. R. Soepratman menjadi lagu kebangsaan (Hatta, 1997).

Kondisi sejarah pemuda ini menggambarkan bahwa masa penjajahan melahirkan sikap senasib sepenanggungan yang kemudian berkembang menjadi semangat kebangsaan. Hal ini dituliskan pula oleh Yudi Latif dalam bukunya yang berjudul mata air keteladanan (2014), yang menggambarkan bahwa, bila di lihat dari kenyataan historis kaum muda Indonesia, kesadaraan akan kebangsaan yang sudah ada bukanlah hanya sebatas dari sesuatu yang tiba-tiba jatuh dari langit, melainkan kesadaran itu sengaja dipupuk melalui semangat kebangsaan yang sama. Bahkan semangat heroisme pergerakan pemuda dari beragam latar etnis dan agama yang mendorong percepatan kemerdekaan Indonesia. 


\section{Semangat Kebersamaan sebagai bentuk penerapan semangat Kebangsaan dalam menyelesaikan Wabah Pandemi}

Bangsa dan negara Indonesia memiliki keberagaman dalam berbagai aspek kehidupan, tentu ini merupakan tantangan sekaligus anugerah dari Yang Maha Kuasa. Oleh karena itu, pendiri bangsa ini sangat peka melihat perbedaan, namun juga tidak meruncingkan perbedaan tersebut sebagai benih kebencian. Akan tepai justru perbedaan itulah yang menjadikan bangsa dan negara ini tidak tercerai berai. Pondasi kebangsaan yang kuat adalah sebagai modal utama dalam membangun persatuan, maka dengan kekuatan semangat kebersamaan (kolektivitas), negara ini mampu berdiri tegak meski dalam balutan perbedaan.

Oleh karena itu, siswa sebagai bagian dari perjuangan untuk membangun negeri dan menghadapi pandemi ini, seluruh siswa senantiasa menjalankan nilai-nilai dasar negara dalam setiap kehidupannya sehari-hari maupun dalam berorganisasi. Artinya dengan adanya musibah pandemi ini, sekolah dapat menjadikan sebagai momen titik balik untuk kembali merawat semangat kebangsaan yang selama ini dirobek oleh kepentingan para elit dalam berebut kuasa. Jiwa Pancasila harus terpancar sebagai kepribadian dan jati diri bangsa.

Bung Karno dalam sidang BPUPKI 1 Juni 1945 mengatakan bahwa kita bukan saja harus mendirikan negara Indonesia merdeka, tetapi harus menuju pula kepada kekeluargaan bangsa-bangsa... Kita hendak mendirikan suatu negara "semua untuk semua", "satu buat semua, semua buat satu"... Karena itu, jikalau tuan-tuan terima baik, marilah kita mengambil sebagai dasar negara yang pertama: Kebangsaan Indonesia (Yudi Latif, 2015).

Seluruh stakeholder SMP Muhammadiyah 1 Purwokerto sepakat bahwa wabah pandemi ini merupakan musuh bersama, maka harus diselesaikan secara bersama pula. Maka dari itu, sekolah senantiasa membangun kemitraan yang baik dengan lingkungan keluarga, dan masyarakat. Tujuannya adalah bersama-sama membentuk siswa sebagai generasi muda yang islami, berakhlak mulia, dan yang berguna dalam kehidupan bermasyarakat, berbangsa dan bernegara.

\section{SIMPULAN DAN SARAN}

\section{A. Simpulan}

1. Siswa belum memiliki pemahaman yang utuh terhadap konsep wawasan kebangsaan, namun secara implisit dalam proses pembelajaran PPKn, guru senantiasa membangun iklim kebersamaan dan saling membantu. Kondisi ini sebenarnya dapat dipahami jika benih-benih semangat kebangsaan telah muncul. Pemilihan metode pembelajaran yang bervariatif digunakan oleh guru PPKn dan guru IPS, yang 
menunjang terhadap sikap kebangsaan siswa. Pembelajaran PPKn dan IPS yang dilaksanakan memberikan kontribusi yang cukup besar dalam membentuk semangat kebangsaan siswa di sekolah yang ditandai dengan arah pencapaian keberhasilan belajar yang tidak hanya melihat aspek kognitif saja, namun dititikberatkan pula pada aspek afektif dan psikomotor khususnya yang bermuatan nilai-nilai kebangsaan.

2. Memperkuat organisasi dengan pondasi semangat nasionalisme yang dilandasi oleh ideologi negara dan nilai-nilai Muhammadiyah. Melalui komitmen organisasi yang kuat, maka semangat kebangsaan mengalir dalam diri siswa.

3. Praktik semangat kebangsaan siswa diwujudkan melalui partisipasinya dalam kegiatan pramuka kepanduan HW, kegiatan upacara bendera, kompetisi olahraga serta acara kesenian daerah merupakan bentuk rangsangan dalam mengembangkan nilai-nilai kebangsaan dalam diri siswa dan tidak menyebarkan berita hoax tentang pandemi covid 19.

\section{B. Saran}

1. Seluruh stakeholder diharapkan dapat selalu memberikan motivasi dan kesempatan yang seluas-luasnya kepada siswa untuk mengembangkan potensi dan meningkatkan kompetensinya dalam melaksanakan pembelajaran yang bermakna.

2. Kepada siswa, diharapkan agar dapat memberdayakan seluruh kemampuannya untuk lebih aktif di dalam kegiatan pembelajaran maupun ekstrakurikuler. Serta terus memupuk nilai-nilai kebangsaan sebagai bangsa Indonesia.

\section{DAFTAR PUSTAKA}

Cresswell, J.W. 1994. Research Design: Qualitative and Quantitative Approaches. London: SAGE Publications . 1998. Qualitative Inquiry. Choosing among five Tradition: Sage Publicatons

Hatta, Mohammad. 1997. Edisi II; Demokrasi Kita, Bebas Aktif, Ekonomi Masa Depan. Jakarta: UI Press

Kurnia, H. (2016). SIKAP NASIONALISME MAHASISWA UNIVERSITAS COKROAMINOTO YOGYAKARTA TAHUN AKADEMIK 2015-2016. Academy of Education Journal, 7(2), 79-88. https://doi.org/10.47200/aoej.v7i2.405

Kusumawati, I., \& Kriswanto, Y. (2013). PENDIDIKAN KARAKTER DI SEKOLAH DASAR NEGERI BRENGOSAN 1 KECAMATAN NGAGLIK KABUPATEN SLEMAN. Academy of Education Journal, 4(1). https://doi.org/10.47200/aoej.v4i1.93

Latif, Yudi. 2014. Mata Air Keteladanan. Pancasila dalam Perbuatan. Jakarta Selatan: Mizan 2015. Negara Paripurna: Historisitas, Rasionalitas dan Aktualitas Pancasila. Jakarta: PT Gramedia Pustaka Utama 
Lincoln, Y.S. \& Guba, E.G. (1985). Naturalistic Inquiry. Baverly Hills: Sage Publications

Miles, M.B. \& Huberman, A. M. (1992). Analisis Data Kualitatif: Buku Sumber tentang Metode-metode Baru. Terjemahan oleh Tjetjep Rohendi Rohidi dari judul Qualitative Data Anlysis. Jakarta: Universitas Indonesia Press

Sugiman, A. M. (2017). PENANAMAN NILAI-NILAI NASIONALISME DAN PATRIOTISME MELALUI MATERI SIKAP SEMANGAT KEBANGSAAN DAN PATRIOTISME DALAM KEHIDUPAN BERMASYARAKAT, BERBANGSA DAN BERNEGARA PADA PEMBELAJARAN PKn DI SMAN 1 PUNDONG. Academy of Education Journal, 8(2), 174-199. https://doi.org/10.47200/aoej.v8i2.370

Undang-Undang Dasar Negara Republik Indonesia Tahun 1945

Yin, K.R. 2008. Case Study Research: Design and Methods (Applied Social Research Methods). Illinois: Sage Publications, Inc

Winataputra dan Budimansyah, D. 2007. Civic Education. Bandung: Program Studi Pendidikan Kewarganegaraan

Zamroni. 2011. Pendidikan Demokrasi pada Masyarakat Multikultural. Yogyakarta: Gavin Kalam Utama 